\title{
Apakah Anggaran Pemasaran Pariwisata Pemerintah Efektif dalam Meningkatkan Jumlah Kunjungan Wisatawan?
}

\author{
Oman Sukirman \\ Universitas Pendidikan Indonesia \\ oman@upi.edu
}

(Studi Kasus di Indonesia Tahun 2011-2016)

\begin{abstract}
Our focus is the effect of the tourism ministry budget to promote tourism on the growing number of tourists. We used regression models using data for 2011 through 2016 to identify the impact of tourism marketing budgets on the growth in tourist numbers. The results show that the effect of higher marketing on the growth of the number of tourists depends on the level of tourism marketing budget that is in the ministry of tourism. More specifically, the results show that tourism marketing budgets have a major effect in increasing the number of foreign tourists visiting. However, the effect is different if applied to national tourism marketing. For the national tourism marketing budget is less effect in increasing the number of domestic tourists.
\end{abstract}

Keywords- tourism; tourism marketing; tourism marketing budget; number of tourist visits; foreign tourists; local travelers.

\section{PENDAhuluan}

Saat ini pariwisata merupakan suatu sektor yang menjadi unggulan di dunia. Pariwisata merupakan kunci sukses pembangunan, kesejahteraan dan kebahagiaan. Kegiatan pariwisata telah meningkatkan jumlah berbagai destinasi dan jumlah investasi di bidang pariwisata. Peningkatan yang luar biasa ini telah menjadikan pariwisata sebagai faktor penting dalam pendapatan ekspor, penciptaan lapangan kerja, pengembangan usaha dan infrastruktur. Pariwisata telah mengalami perluasan dan diversifikasi terus-menerus, dan menjadi salah satu sektor ekonomi terbesar dan tercepat pertumbuhannya di dunia. Meskipun krisis global telah terjadi beberapa kali, jumlah perjalanan wisatawan internasional tetap tumbuh secara positif. Perjalanan wisatawan telah meningkat pesat, dari sebelumnya berjumlah 25 juta orang pada tahun 1950, bertambah menjadi 278 juta orang pada tahun 1980, kemudian meningkat menjadi 528 juta orang pada tahun 1995 , dan terakhir terjadi lompatan yang luar biasa menjadi 1,1 milyar orang pada tahun 2014 (UNWTO, 2014) (UNWTO, 2015) (Ratman, 2016).

Pariwisata merupakan salah satu sektor ekonomi di Indonesia yang besar dan terus berkembang. Menteri Pariwisata RI, Arief Yahya, berpendapat bahwa pariwisata merupakan kontibutor yang paling mudah dan paling murah terhadap Pendapatan Nasional Bruto (PNB), perolehan devisa, dan lapangan kerja. Pariwisata hanya membutuhkan 5.000 dolar Amerika untuk menciptakan satu lapangan kerja penuh, sementara industri lain membutuhkan lebih dari 100.000 dolar Amerika (Yahya, 2016). Kementerian Pariwisata mengestimasi jumlah kunjungan wisatawan domestik dan internasional 280 juta orang pada tahun 2017, dan memproyeksikan angka ini meningkat menjadi 295 juta pada tahun 2019. Jumlah kunjungan wisatawan pada tahun 2015 sebanyak 265,4 juta orang, telah berkontribusi pada (PNB) nasional sebesar $10 \%$, pendapatan devisa sebesar 144 triliun, menyerap tenaga kerja sebanyak 11,3 juta orang. Pariwisata telah berkontribusi $10 \%$ pada PNB Indonesia pada tahun 2015 tumbuh $4.8 \%$ dan berpotensi menjadi $7 \%$ pertumbuhannya mengalahkan sektor agrikultur, manufaktur, dan industri lainnya. Dalam penyerapan tenaga kerja pada tahun 2015, sektor pariwisata telah berkontribusi sebesar $8.4 \%$ skala nasional. Penyerapan tenaga kerja di sektor pariwisata telah tumbuh $30 \%$ dalam periode 5 tahun terakhir. Kontribusi pariwisata terhadap perolehan devisa pada tahun 2015 sebesar $9.3 \%$, telah tumbuh sebesar $13 \%$ berbeda dengan empat sektor lainnya yang pertumbuhannya negatif. Bila dibandingkan dengan jumlah devisa yang dihasilkannya, biaya pemasaran pariwisata yang telah dikeluarkan pemerintah hanya sebesar $2 \%$ dari perolehan devisa sektor pariwisata (Yahya, 2016) 
Dengan begitu besarnya manfaat yang dirasakan dari kegiatan pariwisata ini, tidak mengherankan apabila pemerintah telah menjadi semakin terkoordinasi dengan baik dan berjuang sekuat tenaga dalam usahanya untuk bersaing memperebutkan pendapatan pariwisata dari jumlah kunjungan wisatawan global, regional, maupun lokal. Ini merupakan suatu hal yang menarik karena sebelum tahun 1950 disebutkan baru ada 15 negara yang melakukan kegiatan promosi pariwisata sebelum dan baru pada awal tahun 1980-an semua negara bagian di Amerika telah mengembangkan kantor pengembangan pariwisata tingkat negara (Richter, 1985). Berdasarkan survey Survei Travel Industry Association (TIA) tentang Anggaran Dinas Pariwisata dan Negara Bagian A.S. tahun 20062007 secara kontras dan tajam, anggaran yang diproyeksikan secara kolektif pada periode 2006-2007 untuk kantor pariwisata di 50 negara bagian mencapai lebih dari 765 juta dolar Amerika, di mana terjadi peningkatan hampir $40 \%$ dari 4 tahun sebelumnya (Travel Industry Association, 2007).

Di tengah persaingan anggaran biaya untuk aktivitas pariwisata ini, masih jarang ditemui penelitian yang mempertanyakan efektivitas promosi pariwisata yang dibiayai negara. Hasil Dalam penelitiannya Williams dan Cartee menyajikan jumlah dana yang diterima dari pajak dibandingkan dengan dana yang dihabiskan negara untuk promosi pariwisata (Deskins \& Seevers, 2010). Tetapi klaim tersebut baru berasumsi dan tidak menyiratkan hubungan langsung dan kausal antara promosi pariwisata negara dan kegiatan pariwisata. Riset lain menunjukan suatu kekhawatiran akan terjadinya pengulangan atau tumpang-tindihnya belanja negara dengan upaya promosi pariwisata oleh pihak swasta (Bonham \& Mak, 1996).

Terlepas dari berbagai kekhawatiran tersebut, penelitian yang tersedia hanya menawarkan sedikit ulasan tentang dampak ekonomi dari pemasaran pariwisata yang disponsori negara. Di sisi lain klaim dari pejabat pariwisata negara sepertinya secara umum telah mendukung efek positif dari pemasaran pariwisata negara. Tinjauan literatur belum menemukan penelitian yang luas yang menggunakan analisis regresi untuk menguji hubungan yang diklaim tersebut. Dengan latar belakang ini, kami melakukan analisis ekonometrik dengan menggunakan data anggaran pemasaran pariwisata untuk periode 6 tahun, dari tahun 2011 sampai 2016, untuk menyelidiki hubungan antara belanja negara untuk pemasaran pariwisata dengan pertumbuhan jumlah kunjungan wisatawan.
Tujuan penelitian adalah sebagai berikut: Pertama, penelitian ini memperluas penelitian dengan meneliti dampak pengeluaran pemerintah terhadap pembangunan ekonomi negara. Secara khusus, kami memeriksa apakah belanja pemerintah untuk pemasaran pariwisata berdampak positif untuk peningkatan jumlah kunjungan wisatawan yang diharapkan menjadi efek pertumbuhan PNB, lapangan kerja, dan pertumbuhan devisa negara. Kedua, hasilnya akan memberikan informasi yang berkaitan dengan kebijakan pemerintah dalam upaya mereka untuk menentukan tingkat optimal pengeluarannya untuk pemasaran pariwisata. Mengingat bahwa pengeluaran ini sebagian besar didorong oleh kekhawatiran terhadap pertumbuhan ekonomi negara, ini harus menjadi wawasan berharga bagi pembuat kebijakan pemerintah untuk promosi pariwisata.

Artikel ini disusun sebagai berikut: Pada bagian kedua, kami meninjau kembali literatur dan penelitian sebelumnya untuk memberikan konteks bagi penelitian kami. Bagian ketiga menjelaskan strategi dan data empiris yang digunakan dalam analisis. Bagian keempat menyajikan hasil dan diskusi yang menyertainya. Bagian terakhir menawarkan konklusi dengan diskusi tentang implikasi kebijakan pariwisata dan penelitian terkait pariwisata.

\section{KAJIAN PUSTAKA}

\section{A. Kegiatan Pemasaran Pariwisata}

Tema dalam literatur penelitian ini adalah mengenai kegiatan pemasaran pariwisata di tingkat negara, meskipun sampai sejauh ini riset akademis tentang promosi pariwisata negara relatif sedikit (Deskins \& Seevers, 2010). Riset yang dilakukan oleh Kirkpatrick dan Brown (Kirkpatrick \& Brown, 1938) dan Richter (Richter, 1985) telah berupaya untuk memberikan paparan deskriptif mengenai kegiatan promosi pariwisata oleh negara di negara-negara bagian di Amerika Serikat. Sementara riset lainnya telah mengkhususkan penelitiannya pada strategi dan upaya khusus yang dilakukan oleh negara bagian dalam usahanya menarik wisatawan. Sebuah riset telah mendeskripsikan citra Virginia sebagai sebuah tujuan perjalanan relatif terhadap negara-negara pesaing lainnya di wilayah ini (Uysal, Chen, \& Williams, 2000). Penelitian lainnya telah berupaya mendeskripsikan pengembangan dan efek dari usaha Oregon untuk membangun merek uniknya (Curtis, 2001). Dan yang terakhir adalah riset yang dilakukan oleh Shields (Shields, A review and evaluation of 2002 state visitors' travel packets: A fifty state study, 2006a) (Shields, State- 
funded tourism marketing: The effectiveness of state travel guides for the college market, 2006b) dan Sirakaya dan Sonmez (Sirakaya \& Sonmez, 2000) yang telah berusaha menunjukan efek brosur pariwisata negara.

Di Indonesia bentuk intervensi pemerintah pada sektor pariwisata adalah dalam bentuk alokasi anggaran, di samping policy regulation. Alokasi anggaran yang diberikan dikhususkan untuk menjalankan segala kegiatan pengembangan kepariwisataan. Perubahan alokasi anggaran kementerian pariwisata dipengaruhi oleh restrukturisasi organisasi dan pengembangan strategi kepariwisataan (Direktorat Jenderal Anggaran, 2016).

\section{B. Efektivitas Anggaran Pemasaran \\ Pariwisata}

Penelitian yang menguji hubungan antara anggaran dan pengeluaran wisatawan telah dilakukan oleh Hunt yang menguji hubungan tersebut dengan menggunakan data dari tahun 1981 sampai 1986 dan menemukan bahwa hubungannya rendah (Hunt, 1990). Hunt melihat hubungan antara pertumbuhan anggaran dan pangsa pasar pengeluaran pariwisata, bahwa dalam waktu 10 tahun antara 1975-1976 dan 1984-1985, dia menemukan bahwa negara-negara yang memiliki pertumbuhan anggaran yang paling kontras mendapatkan pertumbuhan pangsa pasar yang positif, dan sebaliknya, negara-negara yang pertumbuhan anggarannya rendah telah kehilangan pangsa pasarnya. Peneliti lainnya yang telah menemukan dampak promosi pariwisata di tingkat negara bagian adalah Schoenbachler dkk. (Kaminski, Gordon, di Benedetto, \& Schoenbachler, 1995) dan Shields (2006b). Temuan Hunt (1990) telah memberikan masukan terbatas untuk kebijakan modern karena tergantung pada korelasi sederhana. Analisis ekonometrik menguntungkan berdasarkan analisis korelasi yang lebih sederhana karena pendekatan ekonometrik memungkinkan penilaian terhadap kontribusi kausal unik anggaran pemasaran pariwisata terhadap kegiatan pariwisata atau ekonomi karena memungkinkan peneliti mengendalikan faktor yang mempengaruhi variabel dependen dan memungkinkan penyelidikan longitudinal, yang memberikan pemahaman yang lebih baik tentang hubungan berkelanjutan dalam rentang waktu yang panjang.

Berdasarkan penelitian yang telah dilakukan sebelumnya, pertanyaan penelitian kami adalah: Apakah anggaran pemasaran pariwisata pemerintah berkontribusi pada jumlah kunjungan wisatawan. Kami meneliti keterkaitan langsung antara anggaran pemasaran pariwisata dan pertumbuhan kunjungan wisatawan karena diduga promosi pariwisata akan meningkatkan aktivitas ekonomi secara keseluruhan.

Pertanyaan lainnya yang ingin kami ajukan adalah apakah pengaruh anggaran pemasaran pariwisata berdampak sama terhadap kunjungan wisatawan mancanegara dan wisatawan nusantara. Meskipun tidak secara eksplisit dibahas dalam penelitian sebelumnya, para ilmuwan berpendapat bahwa upaya promosi negara mungkin bergantung pada keefektifannya sebelumnya.

Dalam beberapa kasus ditemukan bahwa tidak ada jaminan anggaran pemasaran pariwisata negara bagian untuk memperoleh kesuksesan (Hunt, 1990). Kontras dengan hasil tersebut, Shields (2006b) menemukan bukti bahwa negara yang sebelumnya kurang menarik akan memperoleh manfaat paling banyak dari peningkatan promosi pada calon wisatawan. Hasil studi yang berbeda tersebut mendorong kami untuk menjelaskan masalah ini dengan menganalisa hubungan antara anggaran pemasaran pariwisata dan jumlh kunjungan wisatawan. Selanjutnya dianalisa seberapa besar pengaruh anggaran pemasaran pariwisata terhadap pertumbuhan jumlah kunjungan wisatawan.

\section{Hipotesis}

Berdasarkan tinjauan pustaka dan hasil penelitian yang dilakukan sebelumnya yang telah memberikan gambaran bagi penelitian ini, maka kami berasumsi bahwa anggaran pemerintah untuk pemasaran pariwisata akan berpengaruh secara positif dan signifikan terhadap peningkatan jumlah kunjungan wisatawan.

\section{Metode Penelitian}

Kami menggunakan objek dalam penelitian berupa anggaran pemasaran pariwisata (APW) dan jumlah kunjungan wisatawan (JKW) yang ada dalam laporan kinerja Kementrian Pariwisata. Objek penelitian merupakan merupakan inti dari problematika penelitian (Arikunto, 2006). APW menjadi variabel bebas/independent yang mempengaruhi variabel dependent yaitu JKW.

Kedua variabel terlebih dahulu dideskripsikan menggunakan metode deskriptif. Metode ini berfungsi untuk mendeskripsikan kebenaran fenomena berdasarkan data empirik untuk menjawab permasalahan pada saat riset dilakukan (Ali, 2010). Dengan demikian kami dapat mendeskripsikan mengenai pertumbuhan APW dan JKW. 
Sesuai dengan tujuan penelitian, kami meregresikan kedua variabel menggunakan metode penelitian verifikatif dengan bantuan software SPSS dengan tujuan untuk menguji kebenaran hipotesis (Arikunto, 2006).

Kami menggunakan metode penelitian explanatory research untuk menjelaskan hubungan timbal balik antara variabel dengan pengujian hipotesis (Singarimbun \& Effendi, 2008). Desain penelitian kuantitatif ini menggunakan time series design, karena membandingkan data dalam interval waktu tertentu dengan tujuan melihat data dalam bentuk angka-angka dan juga secara grafik (Fahmi, 2012) (Wijaya, 2013)

Dalam penelitian ini, kami terlebih dahulu mendeskripsikan data untuk melihat pertumbuhannya dari tahun 2012-2016. Selanjutnya data APW diuji pengaruhnya pada JKW menggunakan metode regresi linier sederhana melalui software SPSS. Data yang diolah merupakan data sekunder yang didapat dari laporan kinerja tahunan Kementrian Pariwisata dari tahun 2012-2016.

Dalam penelitian ini, kami mengukur pengaruh APW terhadap JKW melalui estimasi model regresi linier sederhana. Analisis regresi linier sederhana didasarkan pada hubungan fungsional ataupun kausal satu variabel independen dengan satu variabel dependen untuk memprediksikan seberapa jauh perubahan nilai variabel dependen, bila nilai variabel independen berubah-ubah atau naik turun (Sugiyono,2013:261). Adapun persamaan umum regresi linier sederhana adalah:

$$
\hat{Y}=a+b X
$$

di mana $\hat{Y}$ merupakan variabel dependen yang diprediksikan dan $\mathrm{X}$ adalah variabel independen yang mempunyai nilai tertentu.

Model regresi kami dirangkum sebagai berikut:

$$
\mathrm{JKW}=\mathrm{a}+\mathrm{b} \text { APW }
$$

di mana a adalah konstanta yaitu jumlah JKW apabila APW sama dengan 0 dan b adalah koefisien dari APW. Singkatan didefinisikan sebagai berikut: JKW mewakili jumlah kunjungan wiatawan, dan APW merupakan anggaran pemasaran pariwisata. Semua model diperkirakan menggunakan data time series tingkat nasional untuk tahun 2012 sampai 2016.

\section{Hasil PENELITIAN DAN PEMBahasan}

\section{A. Kondisi Umum}

Sektor pariwisata menjadi perhatian penting pemerintah di dalam kebijakan pembangunannya. Sektor pariwisata menjadi prioritas kelima dalam program kerja pembangunan kabinet setelah infrastruktur, maritim, energi, dan pangan. Pemerintah telah menjalankan berbagai program dalam rangka pengembangan sektor pariwisata. Pemerintah telah melakukan penataan destinasi dan pengembangan produk wisata, promosi wisata, pembinaan industri pariwisata, dan penataan kelembagaan untuk pembangunan kepariwisatan Indonesia dalam upaya pengembangan kepariwisataan (Kementerian Pariwisata, 2016).

Dukungan yang berkelanjutan dari pemerintah untuk menjadikan sektor pariwisata sebagai sektor ekonomi strategis telah memperlihatkan hasil yang positif. Kinerja pembangunan kepariwisataan berupaya untuk mencapai 3 target yaitu: kontribusi terhadap PDB, kontribusi terhadap devisa, penyerapan tenaga kerja, jumlah kunjungan wisatawan mancanegara, dan jumlah kunjungan wisatawan nusantara.

Gambaran kondisi umum dari realisasi dan target capaian kinerja Kementerian Pariwisata dapat dilihat pada Tabel 1.

\begin{tabular}{|c|c|c|c|c|c|c|c|}
\hline & 2013 & 2014 & 2015 & 2016 & 2017 & 2018 & 2019 \\
\hline Kontribusi terhadap PNB & $9,2 \%$ & $9,3 \%$ & $10 \%$ & $11 \%$ & $13 \%$ & $14 \%$ & $15 \%$ \\
\hline $\begin{array}{l}\text { Pendapatan devisa } \\
\text { (triliun Rupiah) }\end{array}$ & 110,5 & 133,9 & 144 & 172,8 & 182 & 223 & 275 \\
\hline $\begin{array}{l}\text { Jumlah tenaga kerja (juta } \\
\text { orang) }\end{array}$ & 9,6 & 9,8 & 11,3 & 11,7 & 12,4 & 12,7 & 13,0 \\
\hline $\begin{array}{l}\text { Wisatawan mancanegara } \\
\text { (juta orang) }\end{array}$ & 8,8 & 9,4 & 10,4 & 12 & 15 & 17 & 20 \\
\hline $\begin{array}{l}\text { Wisatawan nusantara } \\
\text { (juta orang) }\end{array}$ & 250 & 251 & 255 & 260 & 265 & 270 & 275 \\
\hline
\end{tabular}

\section{TABEL 1. REALISASI DAN TARGET}

Tabel 1 menunjukan realisasi kinerja Kementerian Pariwisata dari tahun 2013 sampai dengan tahun 2015. Data tersebut menunjukan bahwa kontribusi kegiatan pariwisata terhadap PNB, pendapatan devisa, dan penyerapan tenaga kerja, dari tahun 2013 sampai dengan tahun 2016 telah menunjukan peningkatan. Peningkatan kontribusi tersebut sejalan dengan terus meningkatnya jumlah kunjungan wisatawan baik wisatawan mancanegara maupun wisatawan nusantara. Angka yang tercantum pada tahun 2016-2019 adalah merupakan data target kinerja yang dicanangkan dalam rencana strategis Kementerian Pariwisata tahun 2015-2019.

\section{B. Jumlah Kunjungan Wisatawan}

Pada Tabel 1. dapat terlihat hubungan antara peningkatan jumlah kunjungan wisatawan terus meningkat dari tahun ke tahun dengan peningkatan kontribusi kegiatan pariwisata terhadap PNB, kenaiknya 
pendapatan devisa, dan bertambahnya jumlah tenaga kerja yang bekerja di sektor pariwisata. Pertumbuhan jumlah kunjungan wisatawan dari tahun 2011-2016 dapat dilihat pada Gambar 1.

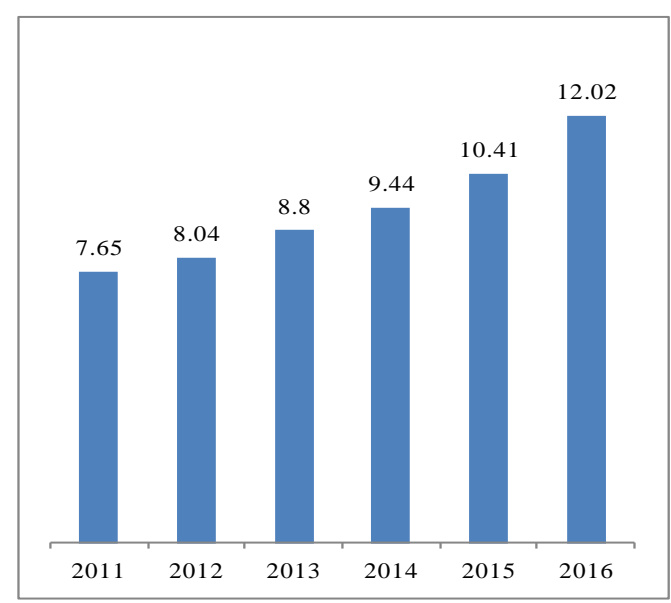

Sumber: LAKIP 2014-2016 dan Direktorat Jenderal Anggaran (2016)

GAMBAR 1. PERTUMBUHAN JUMLAH WISATAWAN MANCANEGARA (DALAM JUTA ORANG)

Gambar 1. Menggambarkan peningkatan jumlah kunjungan dari tahun ke tahun selama periode 5 tahun terakhir. Angka pertumbusan terbesar terjadi pada tahun 2015 yang mencapai angka $15,40 \%$ jauh di atas rata-rata pertumbuhannya yaitu $9,62 \%$. Pesatnya pertumbuhan jumlah kunjungan wisatawan mancanegara ini sangat berbeda dengan kondisi yang terjadi di dalam negeri. Jumlah kunjungan wisatawan nusantara rata-rata pertumbuhannya hanya sebesar $1,96 \%$. Pertumbuhan tertinggi jumlah wisatawan nusantara justru terjadi pada tahun 2012 sebesar 3,80\%, meskipun secara umum tetap mengalami peningkatan dari tahun ke tahun. Pertumbuhan jumlah kunjungan wisatawan nusantara disajikan secara lengkap pada Gambar 2.

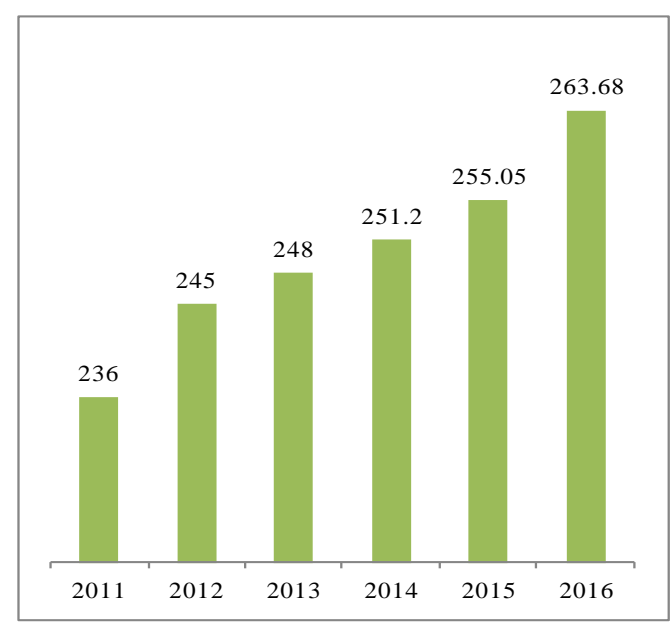

Sumber: LAKIP 2014-2016 dan Direktorat Jenderal Anggaran (2016)

GAMBAR 2. PERTUMBUHAN JUMLAH WISATAWAN NUSANTARA (DALAM JUTA ORANG)

\section{ANGGARAN PEMASARAN PARIWISATA}

Pemerintah telah melakukan intervensi pada sektor pariwisata dalam bentuk alokasi anggaran. Alokasi anggaran diutamakan untuk menjalankan program dan kegiatan pengembangan kepariwisataan. Pada periode 2011-2016, Kementerian Pariwisata telah melakukan beberapa kegiatan utama yaitu kegiatan pengembangan pemasaran, kegiatan pengembangan destinasi, kegiatan penelitian dan pengembangan dan sumber daya manusia, kegiatan kesekretariatan dan pemeriksaan, dan kegiatan ekonomi kreatif dan budaya.

Kegiatan pengembangan pemasaran luar negeri periode 2011-2014 terdiri dari kegiatan peningkatan promosi, konvensi, insentif, even, dan minat khusus, kegiatan pengembangan pasar dan informasi pariwisata, kegiatan peningkatan promosi pariwisata luar negeri, dan kegiatan dukungan manajemen. Sejak tahun 2015 kegiatan pengembangan pemasaran luar negeri mengalami restrukturisasi meliputi kegiatan pengembangan strategi pemasaran mancanegara, kegiatan pengembangan komunikasi pemasaran pariwisata mancanegara, kegiatan pengembangan pasar Asia Tenggara, kegiatan peningkatan dan pengembangan pasar Asia Pasifik, kegiatan peningkatan dan pengembangan pasar Eropa, Timur Tengah, Amerika dan Afrika, dan kegiatan dukungan manajemen. Sementara kegiatan pengembangan pemasaran dalam negeri periode 2011-2014 meliputi kegiatan peningkatan promosi pariwisata dalam negeri dan dukungan manajemen dan sejak 2015 kegiatan ini mengalami penataan kembali menjadi kegiatan peningkatan strategi pemasaran pariwisata nusantara, kegiatan peningkatan analisis data pasar pariwisata nusantara, kegiatan pengembangan komunikasi pemasaran pariwisata nusantara, kegiatan pengembangan segmen pasar personal, kegiatan pengembangan segmen pasar bisnis dan pemerintah, dan kegiatan dukungan manajemen (Direktorat Jenderal Anggaran, 2016).

Untuk mendukung kegiatan pemasaran pariwisata, Kementerian Pariwisata telah mengalokasikan anggaran secara khusus untuk kegiatan tersebut. Anggaran pemasaran pariwisata telah tumbuh seiring dengan pertumbuhan anggaran untuk Kementerian Pariwisata. Meskipun pertumbuhannya cukup berfluktuasi, akan tetapi anggaran pemasaran pariwisata telah secara jelas dialokasikan untuk kegiatan pemasaran pariwisata luar negeri dan kegiatan pemasaran pariwisata di dalam negeri. Untuk melihat bagaimana pertumbuhan anggaran tersebut dapat dilihat pada Tabel 2 . 
TABEL 2. ANGGARAN PEMASARAN PARIWISATA

\begin{tabular}{rrrrrrr}
\hline & $\begin{array}{rrrrr}\text { Anggaran } \\
\text { Tahun }\end{array}$ & $\begin{array}{c}\text { Kemenpar } \\
\text { Perubahan }\end{array}$ & $\begin{array}{c}\text { Anggaran } \\
\text { Pemasaran LN }\end{array}$ & $\begin{array}{c}\% \\
\text { Perubahan }\end{array}$ & $\begin{array}{c}\text { Anggaran } \\
\text { Pemasaran DN }\end{array}$ & $\begin{array}{c}\% \\
\text { Perubahan }\end{array}$ \\
\hline 2011 & 592 & & 448 & & 144 \\
2012 & 842 & $42.23 \%$ & 695 & $55.13 \%$ & 146 & $1.39 \%$ \\
2013 & 1,932 & $129.45 \%$ & 443 & $-36.26 \%$ & 123 & $-15.75 \%$ \\
2014 & 1,508 & $-21.95 \%$ & 288 & $-34.99 \%$ & 85 & $-30.89 \%$ \\
2015 & 2,477 & $64.26 \%$ & 966 & $235.42 \%$ & 349 & $310.59 \%$ \\
2016 & 4,224 & $70.53 \%$ & 2,252 & $133.13 \%$ & 697 & $99.71 \%$ \\
\hline
\end{tabular}

(dalam satuan milyar rupiah)

Sumber: Direktorat Jenderal Anggaran (2016)

Tabel 2. Menunjukan bahwa telah terjadi kenaikan yang luar biasa pada Anggaran Kementerian Pariwisata pada tahun 2013, yaitu naik sebesar $129,45 \%$. Akan tetapi kenaikan tersebut berbeda dengan perubahan yang terjadi pada anggaran pemasaran pariwisata baik untuk pemasaran luar negeri maupun untuk pemasaran dalam negeri yang mengalami penurunan. Pertumbuhan anggaran pemasaran pariwisata terjadi kenaikan yang signifikan pada tahun 2015. Kenaikan ini terjadi pada keduanya, yaitu anggaran pemasaran pariwisata luar negeri dan dalam negeri. Pertumbuhan anggaran pemasaran Kementerian Pariwisata telah diiringi dengan kenaikan anggaran pemasaran pariwisata pada tahun 2015 dan 2016.

Selanjutnya untuk melihat bagaimana hubungan antara anggaran pemasaran pariwisata dengan jumlah kunjungan wisatawan, data tersebut dirangkum dalam Tabel 3.

TABEL 3. ANGGARAN DAN KUNJUNGAN WISATAWAN

\begin{tabular}{rrrrr}
\hline \multirow{2}{*}{ Tahun } & \multicolumn{2}{c}{ Luar Negeri } & \multicolumn{2}{c}{ Dalam Negeri } \\
& Anggaran & Wisatawan & Anggaran & Wisatawan \\
\hline 2011 & 448 & 7.65 & 144 & 236.00 \\
2012 & 695 & 8.04 & 146 & 245.00 \\
2013 & 443 & 8.80 & 123 & 248.00 \\
2014 & 288 & 9.44 & 85 & 251.20 \\
2015 & 966 & 10.41 & 349 & 255.05 \\
2016 & 2252 & 12.02 & 697 & 263.68 \\
\hline
\end{tabular}

(anggaran dalam milyar rupiah, wisatawan dalam juta orang)

Sumber: Direktorat Jenderal Anggaran (2016)

Data dalam Tabel 3. selanjutnya diolah menggunakan software SPSS, untuk menghasilkan output korelasi dan regresi untuk membuktikan hipotesis dengan menganalisis serta mendiskusikannya.

\section{Hasil Pengolahan Data}

Pengolahan data SPSS dilakukan dua tahap yaitu: pertama, untuk menguji korelasi dan regresi antara anggaran pemasaran pariwisata dengan jumlah kunjungan wisatawan mancanegara. Kedua, untuk menguji tentang anggaran dan kunjungan wisatawan nusantara.
Hasil pengujian pertama, menghasilkan luaran software seperti terlihat pada Gambar 3.

\begin{tabular}{|c|c|c|c|}
\hline \multicolumn{4}{|c|}{ Descriptive Statistics } \\
\hline & Mean & Std. Deviation & $\mathrm{N}$ \\
\hline JKW & 9.3933 & 1.62222 & 6 \\
\hline APW & 848.6667 & 727.48489 & 6 \\
\hline
\end{tabular}

\begin{tabular}{|l|c|c|c|c|}
\hline Model & R & R Square & $\begin{array}{c}\text { Adjusted R } \\
\text { Square }\end{array}$ & $\begin{array}{c}\text { Std. Error of } \\
\text { the Estimate }\end{array}$ \\
\hline 1 & $.835^{\mathrm{a}}$ & .697 & .621 & .99832 \\
\hline
\end{tabular}
a. Predictors: (Constant), APW
b. Dependent Variable: JKW

\begin{tabular}{|c|c|c|c|c|c|c|}
\hline \multicolumn{7}{|c|}{ ANOVA $^{b}$} \\
\hline Model & & $\begin{array}{l}\text { Sum of } \\
\text { Squares }\end{array}$ & $d f$ & Mean Square & $\mathrm{F}$ & Sig. \\
\hline \multirow[t]{3}{*}{1} & Regression & 9.171 & 1 & 9.171 & 9.202 & $.039^{9}$ \\
\hline & Residual & 3.987 & 4 & .997 & & \\
\hline & Total & 13.158 & 5 & & & \\
\hline
\end{tabular}

Predictors: (Constant), APW

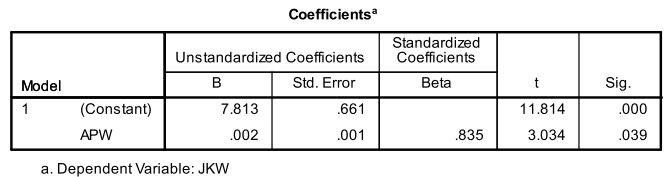

GAMBAR 3. OUTPUT PENGUJIAN PERTAMA

Dan berdasarkan pengujian kedua, diperoleh luaran software seperti tercantum pada Gambar 4.

Descriptive Statistics

\begin{tabular}{|c|c|r|r|}
\hline & Mean & Std. Deviation & \multicolumn{1}{|c|}{ N } \\
\hline JKW & 249.8217 & 9.36903 & 6 \\
APW & 257.3333 & 234.38999 & 6 \\
\hline
\end{tabular}

Model Summary
\begin{tabular}{|l|l|r|r|r|}
\hline Model & R & R Square & $\begin{array}{c}\text { Adjusted R } \\
\text { Square }\end{array}$ & $\begin{array}{c}\text { Std. Error of } \\
\text { the Estimate }\end{array}$ \\
\hline 1 & $.791^{\text {a }}$ & .625 & .532 & 6.41174 \\
\hline
\end{tabular}

a. Predictors: (Constant), APW

\begin{tabular}{|c|c|c|c|c|c|c|}
\hline \multicolumn{7}{|c|}{ ANOVA $^{\mathrm{b}}$} \\
\hline & & $\begin{array}{l}\text { Sum of } \\
\text { Squares }\end{array}$ & df & Mean Square & $\mathrm{F}$ & Sig. \\
\hline \multirow{3}{*}{$\frac{\text { Mode }}{1}$} & Regression & 274.452 & 1 & 274.452 & 6.676 & $.061^{\mathrm{a}}$ \\
\hline & Residual & 164.442 & 4 & 41.110 & & \\
\hline & Total & 438.894 & 5 & & & \\
\hline
\end{tabular}

a. Predictors: (Constant), APW
b. Dependent Variable: $\mathrm{JKW}$

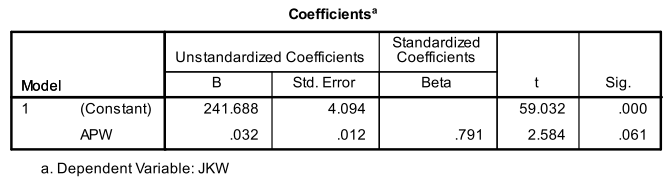

GAMBAR 4. OUTPUT PENGUJIAN KEDUA

\section{E. Diskusi}

Pada Gambar 3. kami melihat adanya hubungan yang sangat kuat $(\mathrm{R}=0,835)$ antara anggaran pemasaran pariwisata (APW) dengan jumlah kunjungan wisatawan (JKW) mancanegara. Dan nilai R Square sebesar 0,697 menunjukan bahwa pengaruh APW terhadap JKW adalah sebesar 69,7\%. Sedangkan hal lain 
yang mempengaruhi naik-turunnya JKW hanya sebesar 30,3\%. Hasil ini menunjukan bahwa APW telah secara nyata dan signifikan berpengaruh positif terhadap JKW. Model persamaan regresi linier yang dihasilkan dari analisis SPSS juga sangat layak, sehingga persamaan regresi untuk menunjukan pengaruh APW terhadap JKW dapat dituliskan menjadi sebagai berikut :

$$
\mathrm{JKW}=7,813+0,002 \mathrm{APW}
$$

Di mana dapat dijelaskan bahwa JKW akan berjumlah sebanya 7,813 juta orang apabila APW bernilai nol. Dan apabila APW tidak sama dengan nol, maka JKW akan meningkat sejumlah 7,813 juta orang ditambah 0,002 kali jumlah APW yang dianggarkan. Hal ini terjadi apabila hal-hal lain di luar JKW dan APW dianggap tetap. Misalnya, apabila APW berjumlah 2.500 milyar, maka JKW akan meningkat menjadi 12,813 juta orang. Atau sebaliknya, apabila JKW mancanegara ditargetkan untuk meningkat menjadi 20 juta orang, maka jumlah APW yang perlu dianggarkan adalah sebesar 6.093,5 milyar. Hasil ini menunjukan kuat pengaruh anggaran pemasaran pariwisata dalam meningkatkan jumlah kunjungan wisatawan mancanegara. Upaya-upaya yang sudah dilakukan oleh pemerintah di dalam menggunakan anggaran pemasaran pariwisata ke luar negeri terbukti telah berjalan secara efektif. Peran pemerintah pusat untuk memasarkan pariwisata nasional di luar negeri sangat penting dalam meningkatkan jumlah kunjungan wisatawan mancanegara.

Berbeda dengan hasil analisis regresi linier pertama, analisis kedua menghasilkan bukti bahwa perubahan JKW tidak secara signifikan dipengaruhi oleh kondisi APW. Meskipun diperoleh nilai $\mathrm{R}$ sebesar 0,791 dan nilai $\mathrm{R}$ Square $=0,625$ tetapi kuatnya hubungan dan besarnya pengaruh APW terhadap JKW ini telah dinyatakan tidak signifikan. Dengan kata lain bahwa APW telah berpengaruh tapi tidak efektif dalam meningkatkan jumlah JKW. Dengan demikian dapat dikatakan bahwa anggaran pemasaran pariwisata nasional tidak memberikan efek yang signifikan (tidak efektif) dalam meningkatkan jumlah wisatawan nusantara. Seperti hasil riset sebelumnya dapatkan bahwa ada kemungkinan pemasaran pariwisata yang dilakukan oleh pemerintah pusat di tingkat nasional tumpang tindih dengan kegiatan pemasaran pariwisata yang dilaksanakan oleh pemerintah daerah atau kegiatan pemasaran pariwisata oleh pihak swasta.

\section{KESIMPULAN}

Dalam penelitian ini kami menyimpulkan bahwa anggaran pemasaran pariwisata telah efektif dalam meningkatkan jumlah wisatawan. Terdapat hubungan yang erat antara anggaran pemasaran dengan jumlah kunjungan wisatawan, dan besarnya pengaruh anggaran pemasaran terhadap jumlah kunjungan wisatawan. Hasil penelitian ini berimplikasi pada penilaian efektifitas anggaran pemasaran pariwisata, dan dapat menjadi bahan rujukan di dalam pengambilan keputusan penetapan anggaran untuk mencapai target jumlah kunjungan wisatawan. Namun, kami menyadari bahwa penelitian ini memiliki kekurangan dari sisi terbatasnya data dan variabel yang hanya membandingkan antara anggaran pemasaran pariwisata dan jumlah kunjungan wisatawan sehingga tidak mampu menggambarkan dampak anggaran pariwisata tersebut pada pertumbuhan ekonomi negara. Sehingga diharapkan untuk penelitian selanjutnya dapat mengkaji efektivitas anggaran pemasaran pariwisata ini dengan melihat berbagai aspek yang menjadi sasaran dari kegiatan pariwisata itu sendiri, misalnya dikaitkan dengan kontribusinya pada pertumbuhan PNB, perolehan devisa, dan jumlah lapangan kerja.

\section{DAFTAR RUJUKAN}

Ali, M. (2010). Metodologi dan Aplikasi Riset Pendidikan. Bandung: Pustaka Cendekia Utama.

Arikunto, S. (2006). Prosedur Penelitian Suatu Pendekatan Praktik. Jakarta: Rineka Cipta.

Bonham, C., \& Mak, J. (1996). Private versus Public Financing of State Destination Promotion. Journal of Travel Research , 35 (2), 3 - 10.

Curtis, J. (2001). Branding a State: the evolution of Brand Oregon. Journal of Vacation Marketing , 7 (1), 75-81.

Deskins, J., \& Seevers, M. T. (2010). Are State Expenditures to Promote Tourism Effective? Journal of Travel Research, $50(2), 154-170$.

Direktorat Jenderal Anggaran. (2016). Kajian di Bidang Penganggaran : Efektivitas Alokasi ANggaran Kementerian Pariwisata terhadap Kunjungan Wisatawan Mancanegaran dan Wisatawan Nusantara. Jakarta: Departemen Keuangan.

Fahmi, I. (2012). Analisis Laporan Keuangan. Bandung: Alfabeta.

Hunt, J. D. (1990). State Tourism Ofifices And Their Impact On Tourist Expenditures. 
Journal of Travel Research , 28 (3), 1013.

Kaminski, P. F., Gordon, G. L., di Benedetto, C. A., \& Schoenbachler, D. D. (1995). Destination advertising: Assessing effectiveness with the Split-Run technique. Journal of Travel \& Tourism Marketing , 4 (2), 1-21.

Kementerian Pariwisata. (2014). Laporan Akuntabilitas Kinerja Kementerian Pariwisata Tahun 2015. Jakarta: Biro Perencanaan dan Keuangan Sekretariat Kementerian Pariwisata.

Kementerian Pariwisata. (2015). Laporan Akuntabilitas Kinerja Kementerian Pariwisata Tahun 2015. Jakarta: Biro Perencanaan dan Keuangan Sekretariat Kementerian Pariwisata.

Kementerian Pariwisata. (2016). Laporan Akuntabilitas Kinerja Kementerian Pariwisata Tahun 2015. Jakarta: Biro Perencanaan dan Keuangan Sekretariat Kementerian Pariwisata.

Kirkpatrick, C., \& Brown, G. (1938). The Sovereign State Turns Barker. Journal of Marketing , 3 (1), 77-83.

Ratman, D. R. (2016, Januari 27). Pembangunan Destinasi Pariwisata Prioritas 2016-2019. Retrieved Oktober 24, 2017, from www.kemenpar.go.id: www.kemenpar.go.id/.../Paparan\%20\%20Deputi\%20BPDIP.pdf

Richter, L. (1985). State-Sponsored Tourism: A Growth Field for Public Administration? Public Administration Review , 45 (6), 832-839.

Shields, P. O. (2006a). A review and evaluation of 2002 state visitors' travel packets: A fifty state study. Journal of Nonprofit \& Public Sector Marketing , 16 (1-2), 61-76.

Shields, P. O. (2006b). State-funded tourism marketing: The effectiveness of state travel guides for the college market. Journal of Travel \& Tourism Marketing , 20 (2), 31-49.

Singarimbun, M., \& Effendi, S. (2008). Metode Penelitian Survei. Jakarta: LP3ES.

Sirakaya, E., \& Sonmez, S. (2000). Gender images in state tourism brochures: An overlooked area in socially responsible tourism marketing. Journal of Travel Research , 38 (4), 353-362.

Travel Industry Association. (2007). 20062007 Survey of U.S. State and Territory Tourism Office Budgets. Washington, DC.: TIA.
UNWTO. (2014). UNWTO Tourism Highlights. Retrieved Oktober 24, 2017, from www.e-unwto.org: http://www.eunwto.org/doi/pdf/10.18111/9789284416 226

UNWTO. (2015, Januari 2). UNWTO World Tourism Barometer Volume 13. Retrieved Oktober 24, 2017, from www.e-unwto.org: http://www.eunwto.org/doi/pdf/10.18111/wtobaromet ereng.2015.13.1.1

Uysal, M., Chen, J. S., \& Williams, D. R. (2000). Increasing state market share through a regional positioning. Tourism Management , 21 (1), 89-96.

Wijaya, T. (2013). Metodologi Penelitian Ekonomi dan Bisnis. Yogyakarta: Graha ilmu Yogyakarta.

Yahya, A. (2016, September 1). Indonesia's Tourism. International Seminar on Halal Tourism . Bandung, Jawa Barat, Indonesia: ITB. 